\section{Plant Spacing Effects on Microclimate and Rhizoctonia Web Blight Development in Container-grown Azalea}

\author{
Warren E. Copes ${ }^{1}$ \\ U.S. Department of Agriculture, Agricultural Research Service, Southern \\ Horticultural Research Station, P.O. Box 287, Poplarville, MS 39470
}

\author{
H. Scherm \\ University of Georgia, Department of Plant Pathology, Athens, GA 30602
}

Additional index words. aerial blight, environmental factors, plant density, stem blight

\begin{abstract}
Rhizoctonia web blight, caused by Rhizoctonia solani and binucleate Rhizoctonia spp., is an annual problem in compact cultivars of container-grown azalea (Rhododendron spp.) in the Gulf Coast states. Increasing the space between plants is commonly recommended for suppression of the disease, but experimental evidence for the effectiveness of this cultural practice in container-grown azalea is lacking. During the summers of 2002 and 2003, disease severity was measured weekly in the inoculated center plant of plots consisting of 49 potted 'Gumpo White' azalea plants growing in 3.8-L containers and having a canopy diameter of about $30 \mathrm{~cm}$. Plant spacing within plots was $0,6,12,18$, or $24 \mathrm{~cm}$, and plots were arranged in three randomized complete blocks. Evaporation, leaf wetness (LW), relative humidity (RH), and temperature were monitored in each plot. Disease severity increased steadily from mid-July to late August or early September, after which it leveled off or declined. Evaporation increased and the number of hours within the temperature range favorable for disease development $\left(25\right.$ to $\left.30^{\circ} \mathrm{C}\right)$ decreased significantly with plant spacing $(P<0.05)$, but $L W$ and $R H$ were not significantly different among treatments. Plant spacing also had no significant effect on disease severity. Daily overhead irrigation and compact plant form likely contributed to the lack of effect of spacing on disease development.
\end{abstract}

Binucleate Rhizoctonia spp. and Rhizoctonia solani cause web blight on many genera of container-grown woody plants (Farretal., 1995; Jones and Benson, 2001). The disease is an annual problem on some azalea (Rhododendron spp.) cultivars in the southern United States. Early symptoms occur after aerial mycelium grows up the stem and infects lower leaves of the inner canopy, but the disease often remains unnoticed until symptomatic leaves are seen at the base of the plant between late June and mid-July in the southern states (Frisina and Benson, 1989; Copes and Scherm, 2004). When weather conditions are conducive for web blight development, the entire foliage of small plants in 3.8-L containers may die and the lower foliage of largerplants in 11.4-Lcontainers may become blighted (W. Copes, unpublished).

The azalea crop in 11 southeastern states had a wholesale value of more than $\$ 45,000,000$ in 1998 (USDA, 1998). Although specific crop loss values for rhizoctonia web blight are not available, based on the senior author's assessment of nursery-wide annual losses due to web blight, about $0.5 \%$ of the plants are killed and $3 \%$ to $8 \%$ are unsaleable during part of the year and experience reduced growth the following year (W. Copes, unpublished).

Received for publication 13 Dec. 2004. Accepted for publication 24 Feb. 2005. We thank Lavonne Stringer for maintenance of fungal isolates, field plots, and weather instruments and Amy Savelle for data entry.

${ }^{1}$ To whom reprint requests should be addressed; emailwcopes@msa-stoneville.ars.usda.gov.
Recommended management practices for web blight include application of fungicides following symptom appearance, discarding diseased plants, and sanitizing production areas after plants have been moved by removing plant residue and applying a disinfestant (Benson and Cartwright, 1996). It is further recommended that plants be spaced far enough apart so they do not touch each other. Although experimental evidence for the effectiveness of the latter practice in container-grown azalea is lacking, it has been documented for other pathosystems that plants grown in dense stands develop more severe disease (Burdon and Chilvers, 1982; Zentmyer and Bald, 1977). Increased plant spacing can reduce humidity within the canopy of some crops by facilitating air movement and sun penetration which accelerate evaporative drying of plant surfaces, providing conditions less conducive for fungal infection (Burdon and Chilvers, 1982; Tu, 1989; Zentmyer and Bald, 1977). In addition, plant spacing can affect disease development by impacting pathogen spread (Berger, 1975) or host growth habit (Yang et al., 1990).

For container-grown azalea, plant spacing is variable among nurseries and between stock at a single nursery (W. Copes, unpublished). Typically, smaller plants that have been potted recently into 3.8 - or 11.4-L pots and/or are destined for mass-market sales are tightly grouped with branch-to-branch or pot-to-pot contact. Proportionally larger plants, regardless of container size, may be spaced with as much as $30 \mathrm{~cm}$ distance between branch tips. Plants are spaced to reduce disease and to achieve a uniform plant form for higher-quality stock.

The annual occurrence of rhizoctonia web blight on azalea grown in containers in the southern United States indicates that environmental conditions are generally favorable for the disease. Rhizoctonia spp. require wet leaf surfaces or relative humidities (RH) of $95 \%$ to $100 \%$ and temperatures from 25 to $30{ }^{\circ} \mathrm{C}$ to infect plant tissue (Ahuga and Payak, 1981; Gross et al., 1998). In a predictive model for brown patch of ryegrass turf (another aboveground disease caused by $R$. solani), mean daily $\mathrm{RH} \geq 75 \%$, leaf wetness (LW) periods $\geq 6 \mathrm{~h}$, or $\mathrm{RH}$ of $95 \%$ or higher for $\geq 8 \mathrm{~h}$ favored disease development (Fidanza et al., 1996). In soybean, regular periods of free moisture and a dense foliage contributed to expansion of rhizoctonia aerial blight (Yang et al., 1990). Azaleas are produced on synthetic surfaces such as polyethylene ground fabrics which likely create microclimate effects different from those experienced in row crop and turf systems. In addition, RH is likely to be different in a nursery cropping system since overhead irrigation is applied daily during the summer when rhizoctonia web blight is a problem. Based on these considerations, the objective of this study was to determine the effect of plant spacing on microclimate and rhizoctonia web blight development in container-grown azalea.

\section{Materials and Methods}

Plot design. The study was carried out at the USDA-ARS Southern Horticultural Research Station in Poplarville, Miss., between July and September in 2002 and 2003. Each year, five plant spacings $(0,6,12,18$, and $24 \mathrm{~cm}$ between the outer canopy edge of each plant) were evaluated using a randomized complete block design with three replications. Each treatment plot consisted of 49 'Gumpo White' plants in 3.8 -L pots in a $7 \times 7$ arrangement. The spacing between plots and blocks was $18 \mathrm{~cm}$ and $6 \mathrm{~m}$, respectively. A $2 \times 7$ plant arrangement with a randomly selected spacing was used at the end of each block. The experiment was set up on polyethylene ground fabric with overhead impact sprinklers. Irrigation was applied twice daily (around $7 \mathrm{AM}$ and 9 PM local time) for $45 \mathrm{~min}$ with $0.75 \mathrm{~cm}$ of water per irrigation event.

Plant material. Rooted cuttings had been transplanted into 3.8 -L pots 16 months before the start of the experiment each year. They were grown in pine bark media and fertilized with 20 g/pot Polyon 17-5-11 fertilizer (Pursell Technologies, Sylacauga, Ala.) at the nursery in March 2002 and April 2003 and with 6 g/pot Scotts Osmocote Pro 19-5-8+ minor nutrients fertilizer (The Scotts Co., Marysville, Ohio) in August 2002 and September 2003. Plants were pruned to a standard canopy diameter of about $30 \mathrm{~cm}$ before the start of the experiment. Shoot growth during the course of the experiment each year was about $2 \mathrm{~cm}$ on select branches. Such growth was mainly at the top and in patches around the canopy, and did not sufficiently impact the space between 
plants to justify moving plants to maintain treatment spacing.

Inoculation. Rhizoctonia solani isolate RS3 (from the collection of D.M. Benson, North Carolina State University, Raleigh, N.C.) was stored in glycerol at $-80{ }^{\circ} \mathrm{C}$. Two to three weeks before inoculum was needed, the fungus was transferred onto acidified potato dextrose agar and grown at $21{ }^{\circ} \mathrm{C}$ under two cool-white fluorescent tubes for 4 to $6 \mathrm{~d}$. Four $1-\mathrm{cm}^{2}$ pieces of agar with the leading edge of mycelium were transferred to barley grain medium in 2002 and rice grain medium in 2003. Grain media were prepared with $150 \mathrm{~cm}^{3}$ of pearled barley or rice

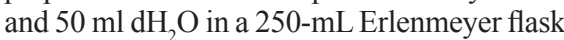
(Gross et al., 1998) and autoclaved twice for 1 $\mathrm{h}$ each. Inoculum was grown for 2 to 3 weeks at $22{ }^{\circ} \mathrm{C}$ under two cool-white fluorescent tubes and shaken daily to maintain individually dispensable grains.

The center plant in each treatment plot was inoculated every 6 to $8 \mathrm{~d}$ by placing a 5 -g aliquot of inoculum (about 150 kernels of colonized grain) near the base of the plant on top of the potting media. The nearest leaves were 0.5 to 8.0 $\mathrm{cm}$ up the stem from the inoculum. The lower tier of branches angled slightly upward from parallel to the ground and typically hung $1 \mathrm{~cm}$ above the outer pot edge. The first inoculation occurred on 12 and 14 July in 2002 and 2003, respectively.

Disease assessment. Limited plant-to-plant spread of web blight occurred in the experimental plots during the study; thus, detailed disease assessments were made only in the inoculated center plant in each plot. Disease severity was assessed every 6 to $8 \mathrm{~d}$ by measuring the total length (in $\mathrm{cm}$ ) of the stem segments that exhibited symptoms of web blight. Disease symptoms along a single, contiguous stem section could include leaves with marginal to interlaminar necrotic lesions, fully necrotic leaves, and defoliated necrotic leaves dangling in mycelial webbing. All symptoms were commonly found on a given plant, but not necessarily on each contiguous section of diseased stem length. All assessments were based solely on symptoms. To make these assessments, individual pots were placed on a sloping table-top $\left(15^{\circ}\right)$, and light was directed into the plant to facilitate viewing of the interior canopy. Then, measurements were taken by aligning two steel rods against a custom-built ruler while pointing the rods at the beginning and end of a contiguous symptomatic stem section without the rods touching the plant. The rods were flamed-sterilized between measurements.

Disease measurements were taken on the entire plant during the first two-thirds of the season in 2002 and for the entire season in 2003. In the later part of the season in 2002, disease severity was high and it became too time-consuming to measure all symptomatic stems per plant; thus, for the remainder of the season disease was assessed in two randomly selected quadrants on each plant, and these measurements were scaled up to the entire plant by multiplying by a factor of 2 . Hereafter, the term "total length of blighted stems" refers to the total length (in $\mathrm{cm}$ ) of stem segments that exhibited symptoms of web blight per plant at a given assessment date, while cumulative length of blighted stems refers to the same measurement summed over all assessment dates.

Environmental variables. Evaporation, $\mathrm{LW}, \mathrm{RH}$, and air temperature were monitored $20 \mathrm{~cm}$ above the ground in each plot, about even with the top of the container and base of the plant canopy. Instruments were placed adjacent to the plot's center plant, with a white ceramic spherical atmometer (C \& M Meteorological Supply, Colorado Springs, Colo.) at the southeastern point, a HOBO H8 Pro Series $\mathrm{RH} /$ Temperature data logger (Onset, Pocasset, Mass.) enclosed within a radiation shield at the southwestern point, and a resistance-type leaf wetness grid (Spectrum Technologies, Plainfield, Ill.) at the northwestern point. All instruments were mounted off the ground on
$4 \times 4 \mathrm{~cm}$ stakes, allowing air-flow beneath and above them. We estimate that no more than $20 \%$ of the circumference of the center plant was affected by the meteorological instruments. Indeed, the atmometers and leaf wetness sensors were small enough that slight variations in overall plant canopy dimension could easily accommodate them, even in the 0 -cm plant spacing. In plots with 0 -cm plant spacing, limbs were pruned throughout the experiment as necessary so that leaves did not contact the metal grid of the wetness sensor. The radiation shield that contained the HOBO datalogger was larger and resulted in the need to skew the plant immediately southwest of the center plant out of position in plots with 0 and $6 \mathrm{~cm}$ spacing. No other plants within the same plot were affected.
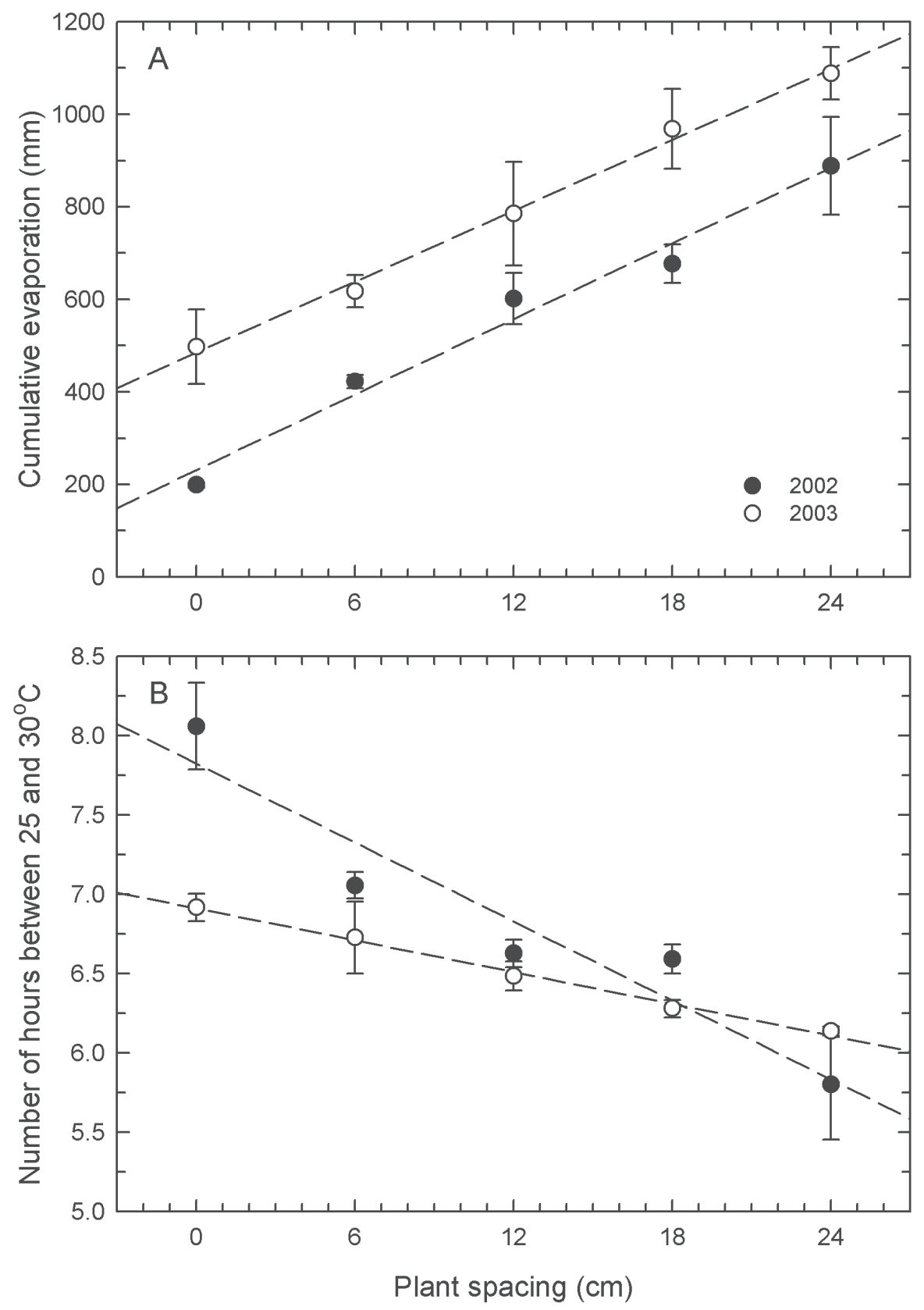

Fig. 1. Effect of plant spacing on (A) cumulative evaporation (from mid-July through mid-September) and (B) the number of hours per day with air temperatures between 25 and $30^{\circ} \mathrm{C}$ in plots of containerized 'Gumpo White' azalea in southern Mississippi. Values are means and standard errors of three replicate atmometers and temperature probes, respectively, for each plant spacing treatment. 
Table 1. Effect of plant spacing on microclimate variables in containerized 'Gumpo White' azalea in 2002.

\begin{tabular}{|c|c|c|c|c|c|c|}
\hline \multirow{2}{*}{$\begin{array}{l}\text { Plant } \\
\text { spacing } \\
(\mathrm{cm})\end{array}$} & \multirow{2}{*}{$\begin{array}{l}\text { Cumulative } \\
\text { evaporation } \\
(\mathrm{mm})\end{array}$} & \multirow[b]{2}{*}{$\begin{array}{c}\text { No. of hours/day } \\
\text { with } \mathrm{T}=25 \text { to } 30^{\circ} \mathrm{C}^{\mathrm{y}}\end{array}$} & \multirow[b]{2}{*}{$\begin{array}{l}\text { No. of hours/day } \\
\text { with leaf wetness }\end{array}$} & \multicolumn{3}{|c|}{ Frequency of days (\%) } \\
\hline & & & & $\begin{array}{c}\text { Mean RH } \\
\geq 75 \% 0^{\mathrm{y}}\end{array}$ & $\begin{array}{l}\geq 8 \mathrm{~h} \text { with } \\
\mathrm{RH} \geq 95 \% \mathrm{y}\end{array}$ & $\begin{array}{c}\geq 6 \mathrm{~h} \text { of } \\
\text { leaf wetness }\end{array}$ \\
\hline 0 & $198.7 \pm 5.2$ & $8.06 \pm 0.47$ & $8.87 \pm 0.41$ & $100.0 \pm 0.0$ & $98.3 \pm 0.0$ & $93.7 \pm 7.0$ \\
\hline 6 & $422.5 \pm 14.4$ & $7.06 \pm 0.14$ & $8.55 \pm 0.16$ & $100.0 \pm 0.0$ & $98.3 \pm 0.0$ & $95.4 \pm 2.0$ \\
\hline 12 & $601.5 \pm 55.2$ & $6.63 \pm 0.15$ & $8.46 \pm 0.21$ & $100.0 \pm 0.0$ & $98.3 \pm 0.0$ & $97.1 \pm 1.0$ \\
\hline 18 & $677.0 \pm 41.5$ & $6.59 \pm 0.16$ & $8.41 \pm 0.06$ & $100.0 \pm 0.0$ & $98.3 \pm 0.0$ & $97.1 \pm 2.0$ \\
\hline 24 & $888.4 \pm 105.7$ & $5.80 \pm 0.60$ & $8.32 \pm 0.14$ & $96.6 \pm 2.4$ & $95.7 \pm 3.7$ & $97.1 \pm 2.0$ \\
\hline \multicolumn{7}{|c|}{ Linear regression results } \\
\hline$r^{2}$ & 0.9791 & 0.9127 & 0.8586 & 0.5000 & 0.5000 & 0.7813 \\
\hline$P$ & 0.0013 & 0.0113 & 0.0236 & 0.1817 & 0.1817 & 0.0467 \\
\hline
\end{tabular}

${ }^{z}$ Values are means \pm standard deviations of individual sensors in three replicate blocks. Measurement period: 23 July through 18 Sept. 2002.

${ }^{\mathrm{y}} \mathrm{T}=$ canopy air temperature, $\mathrm{RH}=$ canopy relative humidity.

Table 2. Effect of plant spacing on microclimate variables in containerized 'Gumpo White' azalea in $2003 .{ }^{2}$

\begin{tabular}{|c|c|c|c|c|c|c|}
\hline \multirow{2}{*}{$\begin{array}{l}\text { Plant } \\
\text { spacing } \\
(\mathrm{cm})\end{array}$} & \multirow{2}{*}{$\begin{array}{l}\text { Cumulative } \\
\text { evaporation } \\
(\mathrm{mm})\end{array}$} & \multirow[b]{2}{*}{$\begin{array}{c}\text { No. of hours/day } \\
\text { with } \mathrm{T}=25 \text { to } 30^{\circ} \mathrm{C}^{\mathrm{y}}\end{array}$} & \multirow[b]{2}{*}{$\begin{array}{l}\text { No. of hours/day } \\
\text { with leaf wetness }\end{array}$} & \multicolumn{3}{|c|}{ Frequency of days $(\%)$} \\
\hline & & & & $\begin{array}{c}\text { Mean RH } \\
\geq 75 \% \%^{y}\end{array}$ & $\begin{array}{l}\geq 8 \text { h with } \\
R H \geq 95 \% 0^{y}\end{array}$ & $\begin{array}{c}\geq 6 \mathrm{~h} \text { of } \\
\text { leaf wetness }\end{array}$ \\
\hline 0 & $497.6 \pm 80.5$ & $6.92 \pm 0.15$ & $7.93 \pm 0.19$ & $100.0 \pm 0.0$ & $96.8 \pm 0.0$ & $84.1 \pm 2.2$ \\
\hline 6 & $617.5 \pm 34.9$ & $6.73 \pm 0.48$ & $8.19 \pm 0.33$ & $100.0 \pm 0.0$ & $94.7 \pm 0.9$ & $87.3 \pm 4.5$ \\
\hline 12 & $784.9 \pm 111.9$ & $6.48 \pm 0.16$ & $7.60 \pm 0.51$ & $99.2 \pm 1.1$ & $93.7 \pm 0.0$ & $83.1 \pm 4.8$ \\
\hline 18 & $968.8 \pm 86.5$ & $6.27 \pm 0.09$ & $7.49 \pm 0.08$ & $100.0 \pm 0.0$ & $93.7 \pm 0.0$ & $84.1 \pm 2.7$ \\
\hline 24 & $1088.2 \pm 56.6$ & $6.13 \pm 0.05$ & $7.48 \pm 0.19$ & $99.2 \pm 1.1$ & $92.9 \pm 1.1$ & $86.1 \pm 5.1$ \\
\hline \multicolumn{7}{|c|}{ Linear regression results } \\
\hline$r^{2}$ & 0.9945 & 0.9933 & 0.6593 & 0.3333 & 0.8536 & 0.0055 \\
\hline$P$ & 0.0002 & 0.0002 & 0.0951 & 0.3081 & 0.0249 & 0.9060 \\
\hline
\end{tabular}

${ }^{z}$ Values are means \pm standard deviations of individual sensors in three replicate blocks. Measurement period: 18 July through 18 Sept. 2003.

${ }^{\mathrm{y}} \mathrm{T}=$ canopy air temperature, $\mathrm{RH}=$ canopy relative humidity.

Atmometers were set up as described previously (Livingston, 1935) and calibrated individually using a factory-supplied coefficient. Water loss due to evaporation (in $\mathrm{mg}$ water per day) was determined by weighing the atmometer every other day. Average RH and temperature were recorded at 15-min intervals. Leaf wetness sensors were connected to Watchdog model 200 or 425 dataloggers (Spectrum Technologies) that were enclosed in radiation shields. The face plate of each wetness grid was set at $45^{\circ}$ angle and faced westward. Wetness sensors recorded the instantaneous value of resistance on a 0 to 15 scale every $15 \mathrm{~min}$. By visually monitoring the time when water was absent from the gird surface, it was determined that surface moisture was present at resistance values $\geq 12$ (data not shown).

Statistical analysis. The relationships between the total length per plant of diseased stem sections and plant spacing and between selected microenvironmental variables and plant spacing were determined by linear regression analysis using PROC REG (SAS version 8.2, SAS Institute, Cary, N.C.). Microenvironmental variables included season-long cumulative evaporation, average LW duration per day, number of hours per day between 25 and $30^{\circ} \mathrm{C}$ (Ahuga and Payak, 1981; Gross et al., 1998), and three moisture variables found previously to be associated with $R$. solani blight on turf, i.e., frequency of days with mean $\mathrm{RH} \geq 75 \%$, frequency of days with $\geq 8 \mathrm{~h}$ of $\mathrm{RH} \geq 95 \%$, and frequency of days with $\geq 6 \mathrm{~h}$ of leaf wetness (Fidanza et al., 1996).

\section{Results}

In both 2002 and 2003, cumulative season-long evaporation increased linearly with plant spacing (Fig. 1, Tables 1 and 2). Indeed, cumulative evaporation was about four (2002) and two (2003) times as high among plants spaced $24 \mathrm{~cm}$ apart compared with those at 0 -cm spacing. While there was no significant difference in regression slopes between the two years $[27.2 \pm 2.3$ (mean \pm standard error) and $25.5 \pm 1.1 \mathrm{~mm} \mathrm{~cm}^{-1}$ in 2002 and 2003, respectively; $P=0.5317$ ], the zero-intercept was significantly greater in $2003(484.9 \pm 16.2$ $\mathrm{mm})$ than in $2002(230.8 \pm 33.8 \mathrm{~mm})$.

In both years, the number of hours per day with temperatures in the range favorable for disease development by $R$. solani $\left(25\right.$ to $\left.30^{\circ} \mathrm{C}\right)$ decreased linearly as plant spacing increased (Fig. 1, Tables 1 and 2). The difference between the 0 - and $24-\mathrm{cm}$ spacings in the number of hours within this range was greater in 2002 (about $2.3 \mathrm{~h}$ ) than in 2003 (about $0.8 \mathrm{~h}$ ).

Moisture variables summarized to reflect environmental requirements of $R$. solani were not consistently affected by plant spacing (Tables 1 and 2). Some individual variables showed significant relationships with plant spacing in one of the two years, but in each case the magnitude of the effect was small (Tables 1 and 2).

Disease severity measured by the total length of all blighted stem segments per plant increased from mid-July to late August 2002 and to early September 2003, after which disease severity leveled off or declined (Fig. 2). The highest average disease severity levels in 2002 and 2003 were 225 and $98 \mathrm{~cm}$ of affected stem length per plant, respectively, corresponding to $25 \%$ and $11 \%$ symptomatic leaf area based on a visual estimate (data not shown). The decrease in total length of blighted stems toward the end of the season was due to the production of new foliage along previously defoliated stems in conjunction with limited to no development of new symptoms. Season-long disease severity, expressed as the cumulative length of blighted stem seg- ments per plant (Fig. 3), was not significantly affected by plant spacing from 0 to $24 \mathrm{~cm}$ in both years $(P=0.8268$ and 0.3863 for 2002 and 2003, respectively). Plant spacing was also not significant when disease severity was assessed with a Horsfall-Barratt scale (Horsfall and Barratt, 1945) or a scale based on percent symptomatic leaf area (data not shown).

\section{Discussion}

Plant spacing is a cultural practice routinely recommended to reduce rhizoctonia web blight in nurseries that grow ornamental shrubs (Benson and Cartwright, 1996). In this study, an increase in spacing from 0 to $24 \mathrm{~cm}$ between the branch tips of adjacent containergrown 'Gumpo White' azalea did not have a disease-reducing effect. Similarly, in commercial nurseries in Alabama and Mississippi, we have observed comparable rhizoctonia web blight severity in azalea grown in 3.8- and 11.4-L pots regardless whether plants were tightly grouped or well-spaced (W. Copes, unpublished).

In a review of plant spacing effects on disease development, Burdon and Chilvers (1982) concluded that disease would be reduced when increased plant spacing interfered with dispersal of pathogen propagules, reduced the number of susceptible plants or plant parts, and/ or changed environmental conditions within the plant toward a less favorable microclimate for infection by the pathogen. In our study, pathogen and host factors remained constant across the spacing treatments: inoculum was added to each plant that was monitored for disease development, and 'Gumpo White' is a compact, susceptible azalea cultivar with a dense foliage, including the lower canopy. The microenvironment was therefore the only factor affected by plant spacing, and the effect 

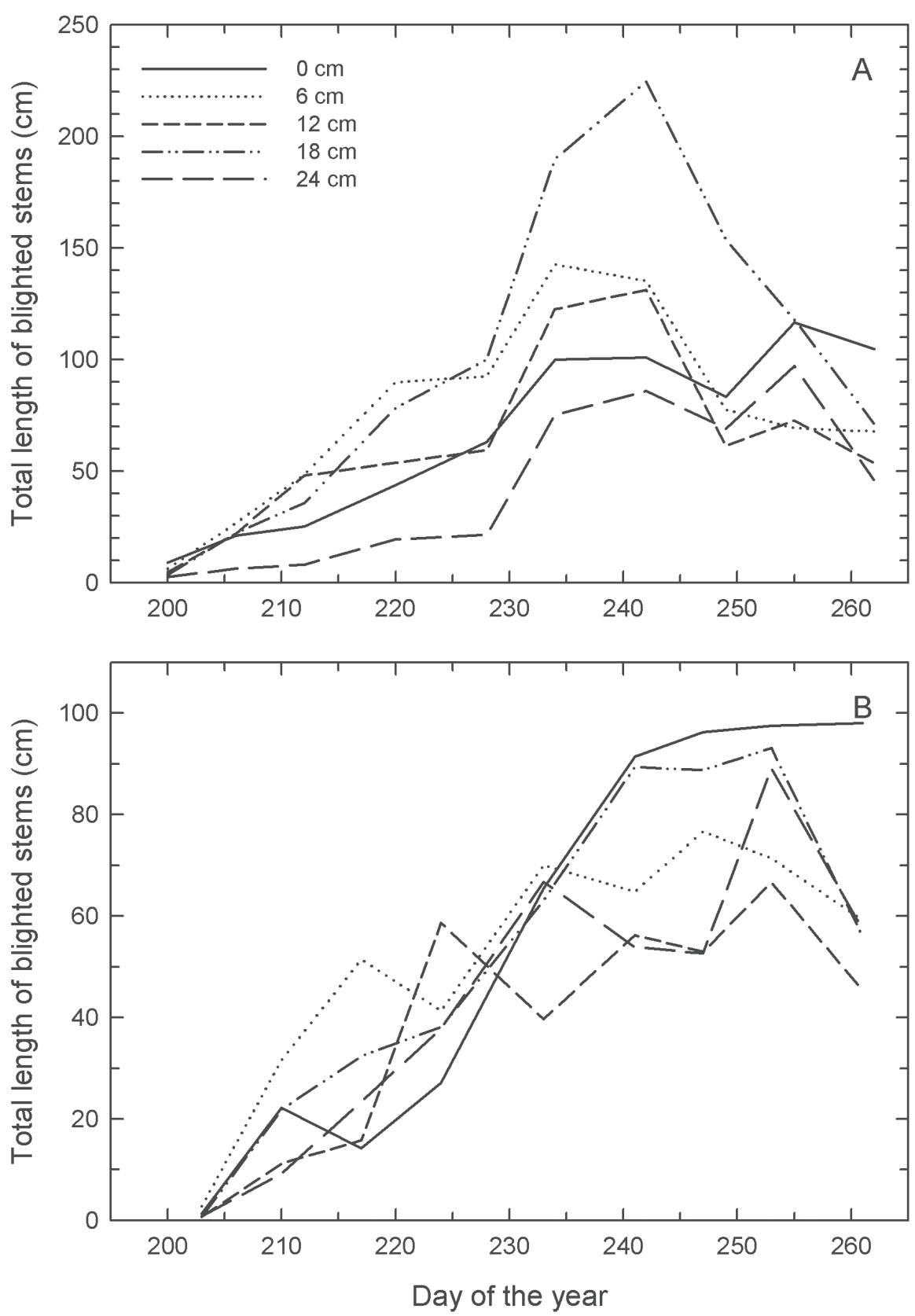

Fig. 2. Temporal progress of rhizoctonia web blight on containerized 'Gumpo White' azalea in southern Mississippi in 2002 (A) and 2003 (B) following artificial inoculation with Rhizoctonia solani. Values are means of three replicate plants for each spacing treatment.

of spacing on microenvironmental variables was apparently not strong enough to modify disease development.

Evaporation was the microenvironmental variable most dramatically influenced by plant spacing, with season-long evaporation being about four (2002) and two (2003) times higher among azalea plants spaced $24 \mathrm{~cm}$ apart compared with those at $0 \mathrm{~cm}$ spacing. This result implies markedly greater drying power of the air among wider-spaced pots. Evaporation involves the absorption of heat that can cause a cooling effect. Indeed, the temperature within the range shown to be favorable for $R$. solani in other pathosystems (corn and ryegrass turf) decreased with plant spacing, and that effect was more pronounced in 2002 when the difference in evaporation between the 0 and 24 the summer months with overhead sprinklers. Although the effects of overhead irrigation on LW duration in crop canopies can be highly variable (Huber and Itier, 1990; Lomas, 1991; Rotem and Cohen, 1966; Rotem and Palti, 1969), this daily supply of water could have provided prolonged average periods of LW and RH uniformly across all plots. Indeed, regardless of plant spacing, LW was maintained on average for at least $7.5 \mathrm{~h} \cdot \mathrm{d}^{-1}$, and $>90 \%$ of the days had $\geq 8$ h with $\mathrm{RH} \geq 95 \%$, conditions considered suitable for infection by $R$. solani in other crops (Fidanza et al., 1996). Thus, frequent irrigation and the associated periods of prolonged LW may have negated the disease-reducing effect of increased plant spacing. This hypothesis should be tested in future experiments with less frequent overhead irrigation or with application of irrigation water via drip system.

Increased plant spacing has been correlated with a reduction in disease in numerous other pathosystems, e.g., white mold on bean $(\mathrm{Tu}$, 1989), cercospora leaf spot on celery (Berger, 1975), and botrytis fruit rot on strawberry (Legard et al., 2000). However, some studies have documented exceptions to the axiom of increased crop density being associated with increased disease development, similar to the results reported here for web blight on azalea. For example, disease severity was unaffected by plant spacing for cercospora leaf spot of celery (Strandberg and White, 1978) and leaf rust of wheat (Pfleeger and Mundt, 1998). In some cases, reduced plant densities have even been associated with higher disease, as was the case with tungro virus disease in rice (Shukla and Anjaneyulu, 1981), sclerotinia stem blight on dry bean (Coyne et al., 1977), and anthracnose on strawberry (Madden and Boudreau, 1997). Increased disease development among more widely spaced plants was due to increased pathogen spread (Madden and Boudreau, 1997; Shukla and Anjaneyulu, 1981), denser growth habit per plant when fewer plants were grown per area (Coyne et al., 1977; Pfleeger and Mundt, 1998; Shukla and Anjaneyulu, 1981), and moisture-related conditions (Strandberg and White, 1978). These results show that multiple factors, in addition to microclimate, interact to influence the magnitude and direction of the plant spacing effect on disease.

The fact that closer plant spacing did not promote rhizoctonia web blight on inoculated plants in the present study implies that a greater number of plants could be produced per area without increasing disease risk. However, data was not sufficient to draw conclusions about spread to noninoculated plants in the same plots. Obvious plant-to-plant spread was observed in commercial nurseries where smaller plants were tightly grouped (W. Copes, unpublished). Furthermore, in soybean, plantto-plant spread of rhizoctonia web blight increased along soybean rows as plant growth created a denser canopy (Yang et al., 1990). Thus, in terms of practical recommendations, it would still be advisable that plants not physically touch neighboring plants because the mycelium of Rhizoctonia spp. could grow 


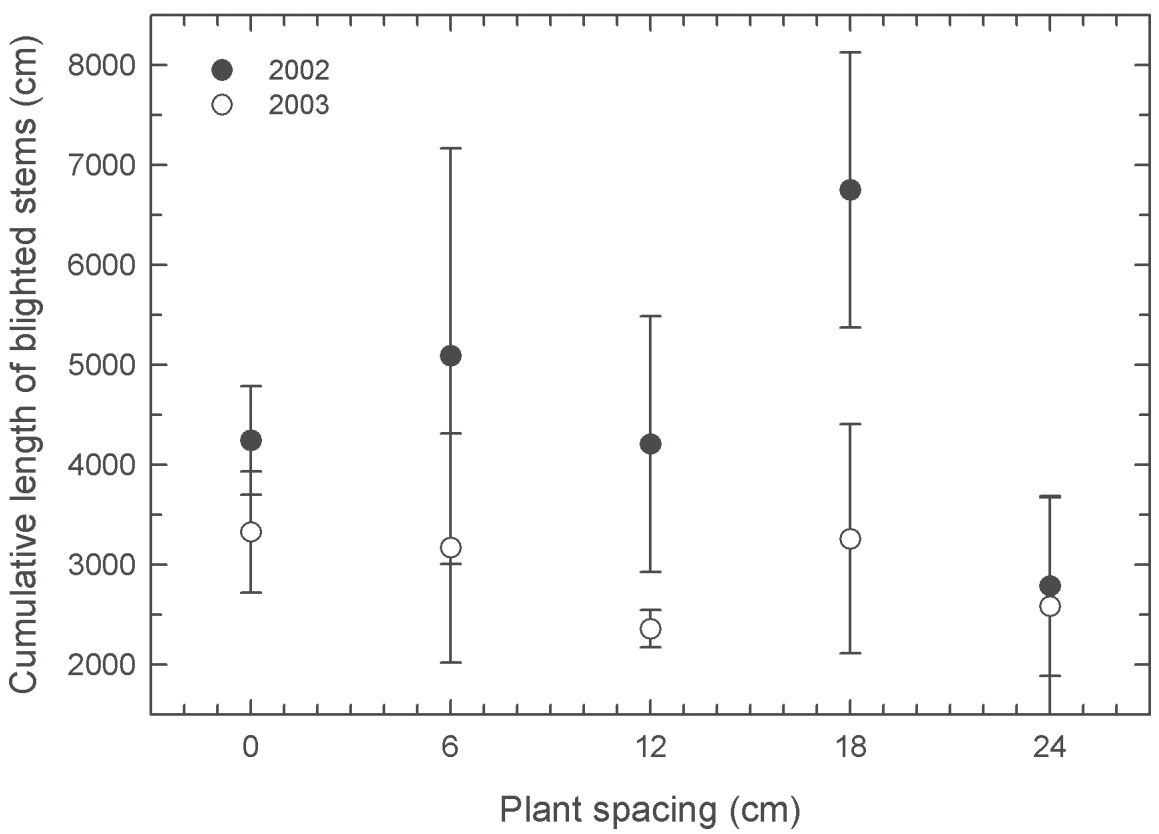

Fig. 3. Effect of plant spacing on season-long cumulative disease severity (from mid-July through midSeptember) on containerized 'Gumpo White' azalea in southern Mississippi following artificial inoculation with Rhizoctonia solani. Values are means and standard errors of three replicate plants for each spacing treatment.

along the branches causing plant-to-plant spread of web blight.

\section{Literature cited}

Ahuga, S.C. and M.M. Payak. 1981. Relationship of relative humidity and temperature levels with the development of leaf and sheath blight of maize. Zeitschrift für Pflanzenkrankheiten und Pflanzenschutz 88:265-268.

Benson, D.M. and D.K. Cartwright. 1996. Ornamental diseases incited by Rhizoctonia spp., p. 303-314. In: B. Sneh, S. Jabaji-Hare, S. Neate, and G. Dijst (eds.). Rhizoctonia species: Taxonomy, molecular biology, ecology, pathology and disease Control. Kluwer, Dordrecht, The Netherlands.

Berger, R.D. 1975. Disease incidence and infection rates of Cercospora apii in plant spacing plots. Phytopathology 65:485-487.

Burdon, J.J. and G.A. Chilvers. 1982. Host density as a factor in plant disease ecology. Annu. Rev. Phytopathol. 20:143-166.

Copes, W.E. and H. Scherm. 2004. Plant spacing effect on microclimate and rhizoctonia web blight development in container-grown azalea.
Phytopathology 94:S21.

Coyne, D.P., J.R. Steadman, and H.F. Schwartz. 1977. Reaction of Phaseolus dry bean germplasm to Sclerotinia sclerotiorum. Plant Dis. Rptr. 61:226-230.

Farr, D.F., G.F. Bills, G.P. Chamuris, and A.Y. Rossman. (eds.). 1995. Fungi on plants and plant products in the United States. APS Press, St. Paul, Minn.

Fidanza, M.A., P.H. Dernoeden, and A.P. Grybausof a brown patch warning model for perennial ryegrass turf. Phytopathology 86:385-390.

Frisina, T.A. and D.M. Benson. 1989. Occurrence of binucleate Rhizoctonia spp. on azalea and spatial analysis of web blight in container-grown nursery stock. Plant Dis. 73:249-254.

Gross, M.K., J.B. Santini, I. Tikhonova, and R. Latin. 1998. The influence of temperature and leaf wetness duration on infection of perennial ryegrass by Rhizoctonia solani. Plant Dis. 82:1012-1016.

Horsfall, J.G. and R.W. Barratt. 1945. An improved grading system for measuring plant diseases. Phytopathology 35:655 (abstr.).

Huber, L. and B. Itier. 1990. Leaf wetness durakas. 1996. Development and field validation tion in a field bean canopy. Agr. For. Meteorol. 51:281-292.

Jones, R.K. and D.M. Benson. (eds.) 2001. Diseases of woody ornamentals and trees in nurseries. APS Press, St. Paul, Minn.

Legard, D.E., C.L. Xiao, J.C. Mertely, and C.K Chandler. 2000. Effects of plant spacing and cultivar on incidence of botrytis fruit rot in annual strawberry. Plant Dis. 84:531-538.

Livingston, B.E. 1935. Atmometers of porous porcelain and paper. Their use in physiological ecology. Ecology 16:438-471.

Lomas, J. 1991. Sprinkler irrigation and plant disease under semi-arid climatic conditions. EPPO Bul. 21:365-370.

Madden, L.V. and M.A. Boudreau. 1997. Effect of strawberry density on the spread of anthracnose caused by Colletotrichum acutatum. Phytopathology 87:828-838.

Pfleeger, T.G. and C.C. Mundt. 1998. Wheat leaf rust severity as affected by plant density and species proportion in simple communities of wheat and wild oats. Phytopathology 88:708-714.

Rotem, J. and J. Ben-Joseph. 1970. Evaporation rate as an indicator for potato late blight development in plots of different foliage density. Plant Dis. Rptr. 54:768-771.

Rotem, J. and Y. Cohen. 1966. The relationship between mode of irrigation and severity of tomato foliage diseases in Israel. Plant Dis. Rptr. 50:635-639.

Rotem, J. and J. Palti. 1969. Irrigation and plant diseases. Annu. Rev. Phytopathol. 7:267-288.

Shukla, V.D. and A. Anjaneyulu. 1981. Plant spacing to reduce rice tungro incidence. Plant Dis. 65:584-586.

Strandberg, J.O. and J.M. White. 1978. Cercospora apii damage of celery - effects of plant spacing and growth on raised beds. Phytopathology 68:223-226.

Thomas, C.S., J.J. Marois, and J.T. English. 1988. The effects of wind speed, temperature, and relative humidity on development of aerial mycelium and conidia of Botrytis cinerea on grape. Phytopathology 78:260-265.

Tu, J.C. 1989. Management of white mold of white beans in Ontario. Plant Dis. 73:281-285.

U.S. Department of Agriculture. 1998. 1998 Census of horticultural specialties. U.S. Dept. Agr., Natl. Agr. Stat. Serv. Stock AC97-SP-2.

Yang, X.B., G.T. Berggren, and J.P. Snow. 1990. Effects of free moisture and soybean growth stage on focus expansion of rhizoctonia aerial blight. Phytopathology 80:497-503.

Zentmyer, G.A. and J.G. Bald. 1977. Management of the environment, p. 121-144. In: J.G. Horsfall and E.B. Cowling (eds.). Plant disease. An advanced treatise. vol I. Academic Press, New York. 